\title{
TIME'S ARROW AS POSTMODERN APOCALYPSE: TEMPORAL RUPTURES, PERPETUAL CRISIS AND THE CULTURAL IMAGINATION
}

\author{
By Laura Wiebe Taylor
}

Martin Amis's 1991 novel Time's Arrow narrativizes two major breaks: a split of consciousness that separates the narrator and protagonist who occupy the same body, and a split in temporality that confuses past and future, so that the narrator attempts to understand the protagonist's life in reverse. ${ }^{1}$ These schisms within the narrative parallel and invoke two major historical ruptures of the twentieth century: the Holocaust that happened, and the nuclear holocaust that looked likely to occur. Time's Arrow, set within this historical framework, suggests these holocausts jointly destabilized the directionality and flow of time, trapping the post-World War Two generations in a perpetual postmodern apocalyptic condition. Following Fredric Jameson, I understand "postmodern" as a "periodizing concept" (3), referring to the cultural logic underlying late modern socioeconomic formations and the expression of that logic in the aesthetic realm. Jameson's analysis of late modern society's pathological relationship with time and history is particularly relevant to Time's Arrow. The novel is postmodern in its literary style, with its destabilized first-person narrative voice and refusal of conventional linear time, but style here expresses a deeper cultural crisis, including the parallel loss of "a sense of history" and of "the sense of a viable future" (Hollinger 166-167). In the ever-present shadow of two catastrophic crises — one lurking behind and one looming ahead — the narrative points to massive devastation in either direction, undermining, but not negating, the conceivability of a (better)

\footnotetext{
${ }^{1}$ This protagonist is variously called Tod Friendly, John Young, Hamilton de Souza, and Odilo Unverdorben. For simplicity, I refer to him throughout as Odilo. I also proceed under the assumption that the narrating consciousness is male because the narration reveals no evidence of gender confusion in relation to Odilo's male body.
} 
future. Amis's novel most powerfully illustrates the continuity between the 'greatest' crises of the twentieth century by portraying apocalypse and rupture as perpetual phenomena, and evoking the difficulty of imagining beyond them.

\section{Historical, Mimetic and Imagined Ruptures}

The Holocaust has been described as "the paradigmatic instance of an apocalypse in history" (Berger 59); ${ }^{2}$ it forms the most "radical break" of the twentieth century, a caesura, forcing a "re-thinking of the relation between past, present and future" and the emergence of the postmodern (Parry 249-51). This conception of the Holocaust informs the postmodern style and the subject matter of Time's Arrow, manifesting in the ruptured temporality of the narrative and the ruptured subjectivity of its main character, both of which hinge on the narrator/protagonist's participation in the Nazi genocide. The novel relates the story of a Nazi doctor, Odilo Unverdorben, working backward from the end of his life through his time serving at Auschwitz, right back to his birth in the years between the First and Second World Wars. Odilo's experience before, after, and particularly during World War Two turns him into a ruptured subject. As a doctor, he is both a healer and a killer, a family man turned solitary war criminal who changes his name and flees to the United States. When Time's Arrow begins, the character has become so alienated from his own body and identity that the first-person narrator only partially recognizes himself in/as the body he occupies. Like Billy Pilgrim in Kurt Vonnegut's Slaughterhouse-Five (1969), the narrating consciousness in Time's Arrow has come unstuck in time-but instead of moving around between past and future, the narrator finds himself experiencing Odilo's life in

\footnotetext{
${ }^{2}$ James Berger admits that imposing an apocalyptic interpretation on the Holocaust carries the risk of suggesting that it represents an "impassable breach in history" or that it offers some kind of revelatory "truth about European culture"; however, the Holocaust's "apocalyptic reverberations" persist (59). Such reverberations permeate Time's Arrow, in which the Holocaust has become a conceptually impassable breach.
} 
reverse so that even speech and motion occur backwards to his perception. The narration's reversed temporality upsets the directionality of cause and effect, past and present. Healing becomes violence, the Holocaust unfolds as the creation of a people rather than their destruction, and the war haunting Odilo's past becomes the narrator's future. War is always looming but has also already happened, and the entire world of the novel appears trapped in a perpetual state of crisis. Inconceivable disaster lays both ahead and behind, and Odilo's life-line cuts history and future possibility short.

The Holocaust represents a major cultural crisis in Time's Arrow, but Nazi genocide is not the only source of catastrophic trauma. The shadow of nuclear war also falls across the narrative. As Amis writes in his essay “Thinkability," published in Einstein's Monsters (1987), something has "gone wrong with time" in the nuclear age, when people are already "experiencing" nuclear annihilation because the "anxiety" and the "suspense" of anticipation is "the only experience of nuclear war that anyone is going to get" (21-22). ${ }^{3}$ In "Thinkability" Amis alludes to a continuity between this ever-present nuclear threat and World War Two when he inserts a reference to the Holocaust museum in Israel in the midst of an argument against nuclear proliferation (26). Amis's reflections on war, time, and the nuclear age in this earlier essay prefigure the narrational ruptures in Time's Arrow and Odilo's relationship to war, suggesting that the novel is concerned with the effects of the Cold War as well as World War Two. Something certainly has "gone wrong" with the narrator's experience of time, and his anticipation of massive destruction is perpetual —even in the midst of Odilo's work at Auschwitz. Linking problems with time to the Holocaust and to the threat of nuclear destruction, Time's Arrow implicates both in apocalyptic rupture.

\footnotetext{
${ }^{3}$ Ronald Granofsky, James Diedrick, and Dermot McCarthy, among others, point to the connections between Einstein's Monsters and Time's Arrow (Granofsky 57; Diedrick 113-14; McCarthy 310-11).
} 
This insight informs Dermot McCarthy's reading of Time's Arrow, which contends that the novel's "metafictive horror" derives from the imminent nuclear holocaust as well as the historical Holocaust: the narrator's backward journey toward the one mirrors the world's forward movement toward the other $(310,303)$. In Time's Arrow, as in Einstein's Monsters, “. . . Amis deals with the terrifying fact that [the twentieth] century has twice confronted us with the limits of the 'thinkable' - the Holocaust of WWII and the potential holocaust of the end of the world" (McCarthy 311). Amis, McCarthy argues, sees the "nuclear age" as the continuation of the Final Solution, with "nuclear holocaust" as the culmination of the "Nazi "project"" (311). Thus the possibility of nuclear holocaust — the "possible destruction of all life" (296) — is implicit in Time's Arrow, shadowing the novel's explicit examination of Nazi genocide.

The continuity between apocalypse, Holocaust and nuclear annihilation in Time's Arrow is most explicit when Odilo is in Portugal; for the protagonist the war has already happened, but the narrator imagines that Odilo's mind and body are "preparing for war" and (as his dream about "shitting human bones" implies) for the revelation of the doctor's role in the atrocities at Auschwitz (Amis 106). Here, the narrator reflects on the bombing of Japan and its implications, suggesting that the use of the atom bomb ("A bomba atómica") marks, or may bring on, "[t]he end of the world" (106). This passage brings the war, the Nazi genocide, the beginning of the nuclear threat, and the possibility of nuclear holocaust together in apocalyptic terms. Later the text imagines the Nazi Holocaust more directly, alluding to what apocalypse might look like: Narrator-Odilo arrives at Auschwitz to find that "[h]uman life was all ripped and torn" (116); he sees the "nearest ruins" "fuming" and "glow[ing]" and "ordure everywhere" (116-17), and the devastation within this "fiercely coprocentric" universe is so great that it seems to exceed human 
control (123). In fact, as the novel suggests, such devastation reaches far beyond the historical context of the death camps.

\section{Perpetual Crisis and Postmodern Trauma}

The traumatic effects of these scenes at Auschwitz echo across space and time so that the narrator identifies similar atrocities in post-War America. The narrator, from his reversed perspective, sees American hospitals as places of pain and death rather than healing. One passage, for example, describes two doctors - Odilo (now called John Young) and a colleague — treating patients by recreating their injuries: "We took the stitches out and swabbed the boys with blood. I remember Witney's skillful insertion of some kind of crossbow bolt; me, I was wedging shards of brown glass into the other boy’s crown" (Amis 83). Caught in crisiswrought confusion, the narrator interprets "medicine's therapeutic role" as "destructive" (Vice 31), and describes New York surgeons in terms that seem better suited to Auschwitz doctors (Diedrick 140). He sees the Nazis, in contrast, as 'creators' engaged in "dream[ing] [rather than destroying] a race" (Amis 120). In the novel's reversed temporality, creation and destruction are confused and combined. Through this confusion, the destabilization of time, and the imagery of war and violence, Time's Arrow entwines postmodernity and genocide as causes and effects of the perpetual apocalyptic condition.

Time's Arrow further marks the effects of continual crisis — of the postmodern apocalypse — through its literary style: both character and narration are ruptured. Odilo, as a Nazi doctor, is implicated in the events that brought on this crisis; he is also heavily invested in denying his culpability, thus it is in relation to his character that we see the most severe effects of apocalyptic trauma, including psychological dissociation. The psychological dimension of 
apocalyptic rupture emerges through the content of the narration, revealing the division of self that separates narrator and protagonist while alluding to post-traumatic stress disorder and to Robert Jay Lifton's theory of psychological doubling. ${ }^{4}$ Claiming to be "innocent," the narrator attempts to evade guilt (Amis 46), persistently fails to remember Odilo's past, and disavows Odilo's body and mind (6-7). This rupture manifests in the anti-realist temporal and narrational split between the first person narrator and the protagonist whose body he occupies. From present to past the narrator (re-) experiences Odilo's memories, walking and hearing things backward and having to translate what he hears and sees (Amis 6-7). He is alienated from his own body and memories, and finds himself in a world that does not make sense $(82,149)$, making him increasingly "tentative about [things like] cause and effect" (44). For the narrator, this about-face toward history signifies Odilo's desire to reverse the trajectory of the Holocaust, undoing the atrocities and his own crimes in an effort to evade moral responsibility. At risk, of course, is turning his helpful actions, such as his attempts to heal, into another source of atrocity and an exposure of his violent past (see Granofsky 63). McCarthy reads the novel's narrational reversal as a source of irony and as a way of illustrating the cancellation of the future that would result from a nuclear holocaust (296-302). However, it is not the impossibility of the future that Amis captures here, but the difficulty of imagining, after the Nazi genocide, a future where threats of genocide have been left behind.

The disorienting narration, refusing a realist chronology, is the key marker of Time's Arrow's postmodern style and its evocation of perpetual crisis. "[C]onfusion" is embedded in the text's very "structure” (Granofsky 57), its “chronillogy” defamiliarizing history and destabilizing the "conventions of mimesis upon which all narrative relies" (McCarthy 303). This entangling of

\footnotetext{
${ }^{4}$ Lifton discusses psychological doubling in The Nazi Doctors: Medical Killing and the Psychology of Genocide (1986); in the afterword to Time's Arrow, Amis thanks Lifton for giving him a copy of this book.
} 
form and content (Vice 12) points to the difficulty of representing the Holocaust, but it also alludes to the impossibility of adequately representing nuclear annihilation; both are unthinkable (McCarthy 310). Subjective schism and temporal reversal evoke the "gap between knowing and understanding" (McCarthy 301), and suggest that the twentieth century's cycle of apocalyptic devastation cannot be contained within conventional narrative or realist conceptualizations of time. The backward trajectory eventually leaves time at a near standstill, the novel's narrative strategies registering the perpetual apocalypse of catastrophic cultural trauma. One passage in particular brings this suspension of time to the foreground: the railway station clock at Treblinka doesn't tell time - the hands are painted on the face and thus never move (Amis 142-43). Here, "time had no arrow" (143) and the moment never passes, never ends.

Confusion of past, present and future is crucial to the novel's depiction of the apocalypse that has and has not (yet) happened. Because the atrocities at Auschwitz form the central initiating events of this postmodern apocalypse, in Time's Arrow it becomes necessary to approach the core of this crisis from both directions - as experiences in Odilo's past and in the narrator's future. For the reader, who understands the reverse trajectory and reconstructs the historical chronology, holocaust must both dwarf the present from behind and loom over it from ahead, suspending conventional temporality. Time, in fact, is one of the last issues the novel raises: "What finally concerns me are questions of time," the narrator remarks in a final effort to be "lucid," to perhaps try to explain his reason for existing as a distinct consciousness (Amis 164). This near-epiphany occurs when he finally sees "an arrow" (time's arrow), fly "[p]oint first," and recognizes that he "came at the wrong time — either too soon, or after it was all too late" (165): or, too soon and too late all at once, for the holocaust that threatens and the one that has already occurred. Odilo and narrator are trapped between them and can prevent neither. 
The narrator's failure to arrive at the right time suggests a painful inevitability, undermining the idea of moral lesson that often underlies apocalyptic narration. What is the use of trying to learn a lesson, when that lesson can never be applied? However, Time's Arrow also points beyond its own cycle of destruction, directing the reader's attention to the possibility of moving outside the text and thus potentially to escape the perpetual, paralyzing state of crisis it depicts. Time's Arrow is strongly intertextual—alluding to Holocaust survival narratives, psychological studies, physics textbooks, and science fiction, among other textual interconnections - and the novel's temporal and intertextual disruptions resist the narrative closure of the traditional novel and the unitary text. ${ }^{5}$ Because of Time's Arrow's postmodern style, when the narrator sees the arrow flying "point first" on the final page it is impossible to determine its ultimate direction, and the novel's continual destabilization of time refuses the predictable resolution of cyclical repetition.

\section{The Postmodern (Post-) Apocalypse}

Nevertheless, the narrative world of Time's Arrow is caught in a postmodern apocalypse. This postmodern apocalyptic condition resonates with what Allan Weiss, writing about Canadian science fiction, describes as “apocalypse without closure" (41). To use Weiss's terms, Time’s Arrow combines elements of the conceptual and the postmodern apocalypse: it feels like "the end of the world as we know it" but the nature of this end is "difficult if not impossible to define" (Weiss 37). ${ }^{6}$ In Amis's novel 'the end,' in a sense, subsumes the narration. While all life

\footnotetext{
${ }^{5}$ Amis flags several of these intertextual connections in his Afterword, including writings by Erick Fromm, Simon Wiesenthal, Isaac Bashevis Singer, Primo Levi, and Kurt Vonnegut. The list drawn up by Amis's critics grows longer and more elaborate, ranging, for example, to Philip K. Dick's "Your Appointment will be Yesterday" (Vice 26-27), Sean O'Faolain's And Again? (Morse 205), and Jonathan Swift's A Modest Proposal (Vice 14).

${ }^{6}$ Compare Veronica Hollinger's analysis of the apocalypse in postmodern fiction: "The postmodern apocalypse is not the end of history; rather, it is the apocalypse within history, our own particular apocalypse, and as such it is and is not singular, it is and is not absolute" (173).
} 
is not yet utterly destroyed, the world after Auschwitz is not quite recognizable, for the narrator at least (Amis 8), and a world beyond this perpetual, immobilizing present seems unknowable, unimaginable. Perpetual apocalypse, for the narrator-protagonist, is a destabilizing inter-crisis condition. Yet, ultimately, it is Time's Arrow's resistance of conventional narrative style that marks the instability and perhaps escapability of this crisis. The novel's rejection of realist representation reminds us that it is, after all, a book, and about one particular character-a fictionalized Nazi doctor. Odilo may be trapped in crisis, with no real history or future, but his fate need not be ours. An apocalypse, even a postmodern one, evokes a post-apocalypse, and this temporal possibility encourages the reader to look beyond the novel's apocalyptic imagery and tone to try to imagine a time outside - and an existence beyond - the condition of perpetual crisis that Amis describes.

Amis's novel is, to a great extent, a product of its context, written by a man who grew up in the shadow of two apocalypses he never experienced. Time's Arrow historicizes humans' catastrophic potential — our capacity, even willingness, to bring apocalypse down on our own collective heads. By 1991, the Holocaust, as large as it still looms, was already beginning to slip from memory into history, and nuclear war was no longer the world's most immediate apocalyptic threat. Current readers are less likely to worry about nuclear holocaust than about climate change or economic catastrophes, as apocalyptic as such fears can become, and for the West, genocide is now more easily displaced elsewhere. ${ }^{7}$ The larger projects Amis's novel participates in, remembering the Holocaust but also remembering the threat of nuclear annihilation, have not lost their poignancy with the start of the new century and new millennium. We need reminding how close these specific horrors remain to the present, but we also need narratives that begin to imagine collective survival otherwise. Outside the bounds of this single

\footnotetext{
${ }^{7}$ For example, genocide has been displaced to Eastern Europe (Bosnia) and to Africa (Sudan, Rwanda).
} 
text, its very unbounded existence implies, we may have the capacity to collectively imagine a future that does not repeat the atrocities of our past. Time's Arrow refuses easy understanding, but its emergence after the end of the Cold War, after at least one apocalypse failed to happen, points to the chance that we may be able to escape a state of perpetual crisis, working through the immobilizing trauma of what has been and what never arrived to imagine and envisage better futures to come. 


\section{Works Cited}

Amis, Martin. Einstein's Monsters. New York: Harmony, 1987.

---. Time's Arrow, or, The Nature of the Offense. New York: Vintage International, 1991.

Berger, James. After the End: Representations of Post-Apocalypse. Minneapolis: $\mathrm{U}$ of Minnesota $\mathrm{P}, 1999$.

Diedrick, James. Understanding Martin Amis. $2^{\text {nd }}$ edition. Columbia: U of South Carolina P, 2004.

Granofsky, Ronald. The Trauma Novel: Contemporary Symbolic Depictions of Collective Disaster. New York: Peter Lang, 1995.

Hollinger, Veronica. "Apocalypse Coma." Edging into the Future: Science Fiction and Contemporary Cultural Transformation. Eds Veronica Hollinger and Joan Gordon. Philadelphia: U of Pennsylvania P, 2002. 159-173.

Jameson, Fredric. The Cultural Turn: Selected Writings on the Postmodern, 1983-1998. London: Verso, 1998.

Lifton, Robert Jay. The Nazi Doctors: Medical Killing and the Psychology of Genocide. London: Macmillan, 1986.

McCarthy, Dermot. "The Limits of Irony: The Chronillogical World of Martin Amis's Time's Arrow." War, Literature and the Arts 11 (1999): 294-320.

Morse, Donald E. "Overcoming Time: 'The Present of Things Past' in History and Fiction." The Delegated Intellect: Emersonian Essays on Literature, Science, and Art in Honor of Don Gifford. Ed. Donald E. Morse. New York: Peter Lan, 1995. 202-23.

Parry, Ann. "The Caesura of the Holocaust in Martin Amis's Time's Arrow and Bernhard Schlink's The Reader." Journal of European Studies 29 (1999): 249-67.

Vice, Sue. Holocaust Fiction. London: Routledge, 2000.

Vonnegut, Kurt, Jr. Slaughterhouse-Five, or, The Children's Crusade: A Duty-Dance with Death. New York: Delacorte/Seymour Lawrence, 1969.

Weiss, Allan. "The Canadian Apocalypse." Worlds of Wonder: Readings in Canadian Science Fiction and Fantasy Literature. In Jean-François Leroux and Camille R. La Bossière, eds. Ottawa: U of Ottawa P, 2004. 35-46. 